\title{
TURNOVER AND INCOME RATE VARIANCE OF SMALL AND MEDIUM ENTERPRISES AND ITS EFFECTS ON SMALL ENTERPRISES' BRAND IDEOLOGY
}

\author{
Langga Anderias Siwa Wunu*, Popo Antonius Talu \\ Department of Business Administration, Faculty of Social and Political Sciences, \\ University of Nusa Cendana, Kupang, Indonesia \\ *E-mail: anderiaslangga@yahoo.com
}

\begin{abstract}
This research was aimed to learn different Small and Medium Enterprises (SMEs) based on the better annual turnover, increased turnover growth, and maximum net income characterized by greater investment in brand ideology (brand orientation, brand identity, and internal brand). The location being studied in this research was Kupang City, the capital city of East Nusa Tenggara. This research used an explanatory design. The population of this research covered 518 SMEs spread across six districts while the number of samples used was 100 SMEs selected using "Proportional Area Sampling" technique. The respondents were also chosen purposively. As the criteria, the SMEs should have a Trade Business License/ Business Place Permit (SIUP/SITU). Data analysis was descriptive statistics and inferential statistics using Partial Least Square method. The constructs were then validated and analyzed further using one way ANOVA and then the hypotheses were tested. The results of this research showed that SMEs with higher annual turnover and positive turnover growth were more concerned with brand ideology compared to those with lower annual turnover and negative turnover growth. Most SMEs had different implementations of marketing and brand ideology. SMEs with a low annual turnover paid less attention to their brands while SMEs with a high annual turnover more prioritized their brands.
\end{abstract}

\section{KEY WORDS}

Turnover growth, brand ideology, brand orientation, brand identity, internal brand.

Branding has an important role for companies in recent decades. This is in line with the increased number of research on brand-specific marketing. In general, research on branding goes against the reality. In developed countries, Small and Medium-sized Enterprises is a business that has strong financial management and the socio-economic life of the people in the countries is well established. Regardless of the role of SMEs in developed countries, various works of literature on branding are more focused especially on large companies only (Krake, 2005). A small portion of the research results on branding becomes biased to conduct further research. According to Gabrielli and Balboni (2010), there is a tendency to assume that marketing principles are equally applicable for either small or large enterprise. However, the slow progress of research on SME marketing shows that small enterprises differ from large enterprises, particularly in relation to brands (Berthon et al., 2008; Krake, 2005; Wong dan Merrilees, 2005).

Gilmore et al. (2001) and Reijonen and Laukkanen (2010) argue that marketing in SMEs is often haphazard, informal, loose and unstructured while that in large enterprises appears formal, planned and structured. Differences not only emerge between small and large enterprises but also between similar SMEs (Reijonen and Laukkanen, 2010). Therefore, this research more focuses on SMEs operating in Kupang City and examines whether there are differences in turnover and revenue rates of similar SMEs, as well as its effects on the brand ideology of small enterprises.

This research was aimed to determine: (1) the better annual turnover, turnover growth, and net income rates of SMEs characterized by high brand orientation; (2) the variance of better annual turnover rates, turnover growth, and net income of SMEs characterized by greater investment in brand identity; and (3) the variance of better annual turnover, turnover 
growth, and net income rates of SMEs characterized by greater investment in internal branding.

\section{LITERATURE REVIEW}

Brand Orientation. Brand orientation is a relatively new concept in branding literature. After being introduced by Urde (1994), this concept remains separated from the research spotlight for several years. But lately, academics have directed their interest in the concept of brand orientation (Baumgarth, 2010; Ewing and Napoli, 2005; Laukkanen et al., 2010; Tuominen et al., 2009; Wong and Merrilees, 2008). Along with the increasing number of studies, several definitions have been proposed. In defining brand orientation, Urde (1999) connects it with the development of brand identity. Meanwhile, Bridson and Evans (2004) defined brand orientation to indicate the extent to which brands are valued in organizations and as a result, are practised. In contrast, Wong and Merrilees (2008) defined brand orientation as a mindset supporting brands in marketing strategies. The findings of several recent researches (Baumgarth, 2010; Wong dan Merrilees, 2008) have suggested that brand orientation has a positive effect on brand performance. The concept of brand performance is a prerequisite for financial performance (Keller, 1993; Lassar et al., 1995). Furthermore, their studies suggest that high financial performance indicates a high level of commitment to brand ideology, especially brand orientation.

Brand Identity. Most brand-oriented companies must engage in the development of brand identity (Reid et al., 2005; Urde, 1999). However, if there are only attitudes or mindset that is brand-oriented, it will not always bring success, especially if the attitudes and mindset are not applied properly (Wong and Merrilees, 2005. Therefore, Aaker and Joachimsthaler (2002) gave the concept of brand identity consisting of three layers, namely (1) brand essence (i.e. what is the brand?); (2) core identity (i.e. mission, vision, values); and (3) additional identity (brand personality). Meanwhile, Ghodeswar (2008) adopted the three layer-based approach to brand identity by suggesting the need of establishing a core brand identity (i.e. mission, vision, values). The core brand identity must be performed permanently, and then additional identity can be made, including brand personality. Thus, the development of brand identity must begin by determining the brand's vision (de Chernatony, 1999) and thereafter establishing brand values (Keller, 2003).

Brand values can attract and bind customers to a company (Urde, 2003). For the purpose of integrated brand communications, visual symbolization of the brand must be able to promote the intangible brand identity (Kapferer, 1997). This is in line with de Chernatony (1999)'s opinion stating that the component of brand identity is a key to success. Companies are striving for coherence in brand communication that will strengthen their positions on the whole in the eyes of customers (Urde, 1994). As a result, the sales and profit figures of companies must follow it, related to whether the company's sales turnover and profit are increased, fixed, fluctuating, or decreased due to changes.

Internal Brand. Internal branding is a coordinated program designed to educate employees on brand messages (Aurand et al., 2005). When product features are easy to duplicate, the service may be the only differentiating factor between competing companies. Companies, especially those operating in the service industry (McDonald et al., 2001), should also ensure that their employees promote coherent brand messages through their behaviours during providing their best service (Henkel et al., 2007; King and Grace, 2006). By communicating the brand messages to employees, they become aware of the brand and support the brand promise (Papasolomou and Vrontis, 2006).

Building a brand identity will be in vain if employees do not support through their behaviours (Aurand et al., 2005). However, internal brands should not limit to educate current employees only, but also should cover recruited or prospective employees (King and Grace, 2006). The success of a brand (service) is based on the employee's service and their behaviours during the service (de Chernatony and Segal-Horn, 2003).

The results of Hirvonen and Laukkanen (2011) showed that in terms of annual turnover, companies with a low turnover are found to lack brand orientation, and pay less 
attention to the development of internal brands and brand identities. Meanwhile, regarding the turnover growth, the difference is not too significant. In fact, after analyzing the results of the $F$ test to provide Hoc testing, significant differences are only identified with regard to brand identity. Therefore, the tendency of companies that have a high turnover growth is more on the brand identity.

\section{METHODS OF RESEARCH}

The location being studied in this research was Kupang City, the capital city of East Nusa Tenggara where many activities of small and medium enterprises take place. This research was initially planned to be conducted in two phases, starting from 2016 to 2017. However, it was finally only done in the first year (2016). This research was an explanatory research, trying to explain the relationship between variables through hypothesis testing. Quantitative research was also used to analyze data and samples with descriptive statistical and inferential statistical analysis methods generalized to population conclusions.

Population and Sample. The population of this research was all households of SMEs, not Rural Banks (RBs) or Micro Finance Institutions (MFIs) listed in Kupang City. The total number of the population was 518 households (Cooperative and SME Office of Kupang City, 2013 in LAKIP of Kupang City, 2014). The sampling was done proportionally to the sample area (Proportional Area Sampling) based on the spread area of SMEs in six districts in Kupang City.

Error tolerance ranging between $5 \%-10 \%$ is aimed at the social science domain. In line with that, the error tolerance of this research was determined $9 \%$, so the sample size or number can be set based on Slovin Formula, $n=N / \mathrm{Nd}^{2}+1$. Using this formula, the number of samples of this research was obtained 99.69 rounded to 100 households of companies (SMEs). Then, the size or number of sub-samples was determined to be taken from each population area while the samples of SME households taken as respondents were selected purposively according to the criteria for listed companies, one of which is to have Trading Business License (SIUP) or Business Place Permit (SITU).

Data Collection and Questionnaire Measurement. This research used primary and secondary data types. Data collection was conducted using questionnaire, interview, and observation techniques. Primary data were collected through instruments in the form of structured questionnaires. Statements in the questionnaire were presented using five points of the Likert scale, in which the lowest point is 1 (one) indicating 'strongly disagree' and the highest point is 5 (five) indicating 'strongly agree'. The questionnaires were distributed to 100 households of SMEs operating in Kupang City that offered products/services in various industrial business, representing all companies including SMEs of Rural Banks/ Micro Finance Institutions.

The research questionnaire included 21 statement items compiled with reference to some literature, covering: brand orientation variable consisting of 5 statement items adopted from Wong and Merrilees (2008); brand identity variable consisting of 8 statement items which were a combination of existing items and some newly-developed items referring to Ewing and Napoli (2005), Hankinson (2001), Reid et al. (2005), Urde (1999), Wong and Merrilees (2008); internal branding variable consisting of 8 statement items which were a combination of items developed by Aurand et al. (2005), Hankinson (2001), and Henkel et al. (2007). Before used, the instrument was tested first.

Data Analysis Technique. The collected data were analyzed with the assistance of Microsoft Excel and Statistics Program for Social Sciences (SPSS) softwares, covering: (a) Descriptive statistical analysis using coding, editing, percentage, average, and cross tabulation procedures, and (b) Inferential statistical analysis using Partual Least Square (PLS) analysis, path diagrams, instrument measurement model evaluation (convergent validity through loading factor and convergent validity through Average Variance Extracted (AVE)), reliability evaluation, Goodness of Fit Model, T-test, Determinant Coefficient Test $\left(R^{2}\right)$, conversion of path diagram into Structural Model, dominant effects, Variance Analysis (ANOVA), F-Test, and Least Square Difference. 
Research Conceptual Model and Hypothesis Development. Based on the research objectives and literature review presented earlier, the conceptual framework of this study was "Is the variance of annual turnover, turnover growth, and net income rates of SMEs have an effect on brand ideology including brand orientation, brand identity, and internal brand of small enterprises?", presented in Figure 1 as follows:

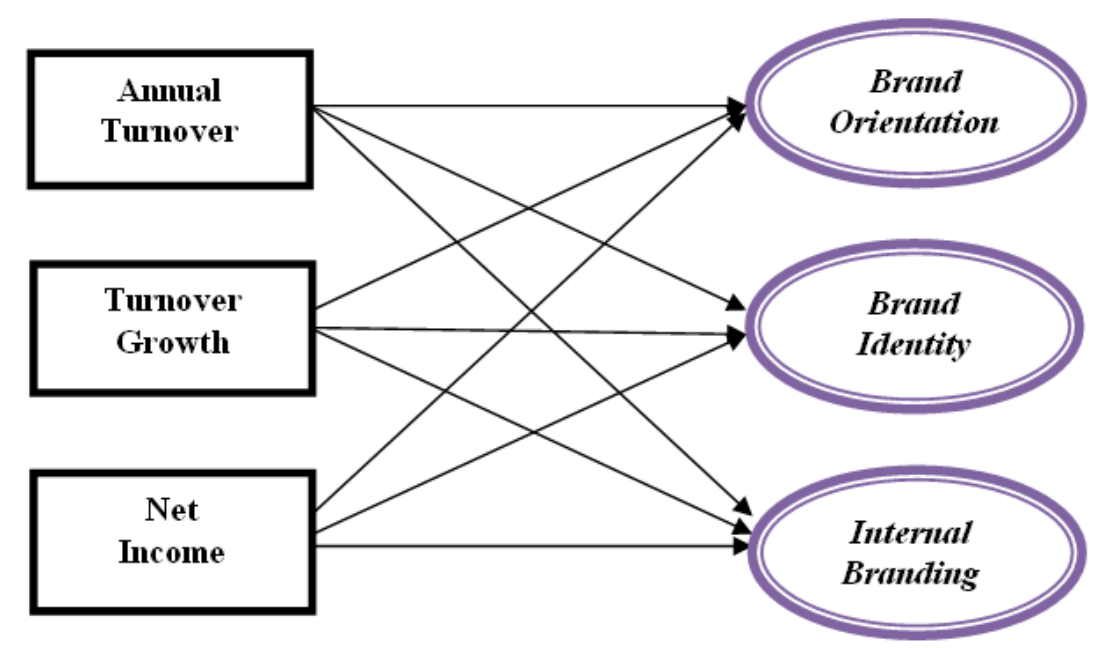

Figure 1 - Research Conceptual Model

Hypothesis Development. Based on the research conceptual model, the hypotheses of this research are as follows:

- H1.1: Better annual turnover is characterized by high brand orientation;

- H1.2: Positive turnover growth is characterized by high brand orientation;

- H1.3: Maximum net income is characterized by high brand orientation;

- H2.1: Greater annual turnover is characterized by greater investment in brand identity;

- H2.2: Positive turnover growth is characterized by greater investment in brand identity;

- H2.3: Maximum net income is characterized by greater investment in brand identity;

- H3.1: Greater annual turnover is characterized by greater investment in internal branding;

- H3.2: Positive turnover growth is characterized by greater investment in internal branding;

- H3.3: Maximum net income is characterized by greater investment in internal branding.

\section{RESULTS AND DISCUSSION}

Overview of SMEs in Kupang City. Kupang City is located at the west end of Timor Island in the southern part of the Republic of Indonesia. Kupang City serves as the entryand-exit gate of local, regional and national traffic flows of people, goods and service.

To improve the welfare of the community, the Municipal Government of Kupang City is committed to empower the community and provide the widest opportunity for the citizens to develop their economic potentials. Concrete steps conducted by the government are increasing the role of cooperatives and SMEs. In 2013, the indicator achievement realization of the SME number of non-Rural Banks and Micro Finance Institutions in Kupang City reached 518 SMEs $(103.6 \%)$ from the targeted number of 500 SMEs, while the number of active cooperatives was 402 units $(80.4 \%)$ from the targeted number of 500 units. 
Law Number 20 of 2008 concerning Micro, Small and Medium Enterprises suggests that SMEs aim to grow and expand their businesses in establishing and developing the economy of the community. SMEs are small-scale economic activities of the people in which the business fields are mostly small business activities. The Municipal Government of Kupang City is continuing to courage efforts to increase the capacity of business capital through the provision of unsecured soft loans, developed through Micro Finance Institutions.

The description of SMEs in Kupang City is presented in Table 1, while that of respondents is shown in Table 2.

Table 1 - Description of SMEs in Kupang City

\begin{tabular}{|l|l|l|l|l|l|}
\hline Characteristic & Item & Percentage (\%) & Characteristic & Item \\
\hline SME Category & Small Business & 79 & License Ownership & SIUP/SITU & Sercentage (\%) \\
& Medium Business & 21 & 30 & SME & Kota Lama \\
\hline Year of & 2013 & 18 & Location & Kota Raja \\
SME & 2011 & 14 & (Districts) & Alak \\
Establishment & 2010 & 10 & & Maulafa \\
& 2012 & 17 & & Oebobo \\
& 2008,2009 & 7 & & 15 \\
& $2002,1998,2005$ & & & Kelapa Lima \\
& $2003,2004,2006,2007$ & 4 & & \\
\end{tabular}

Source: Primary Data.

Description of Research Variables. The questionnaire consisted of 21 statement items and 5 respondent answer scales. Description of perception from 100 respondents on the three endogenous variables is as follows:

Brand Orientation (BO) was measured by 5 statement items. The BO-1 item reached an average score of 4.02 , indicating that the respondents agreed if a brand is very important for their company strategy. The average score of the BO-2 item was 3.78, meaning that the respondents also agreed if a brand flows through all marketing activities. In similar, the average score of the BO-3 item was 3.94, signifying that the respondents again agreed if a brand is highly important for operating their businesses while the average score of the BO-4 item was 4.16 , meaning that the respondents agreed if their long-term brand planning is also greatly essential for the future success of their companies. Meanwhile, the BO-5 item obtained an average score of 4.04, indicating that they also agreed if a brand is a crucial asset for them. If summed up, the average score of the Brand Orientation (BO) variable, on the whole, came out at 3.99, belonging to the "good" category.

Brand Identity $(\mathrm{BI})$ was measured by 8 statement items. The average score of the $\mathrm{BI}-1$ item was 3.33 , meaning that the respondents tended to be neutral that their brands were different from their competitors' brands. As for the BI-2 item, the average score reached 3.40, indicating that the respondents also tended to be neutral, creating a personalized and impressive brand. Meanwhile, the average score of the Bl-3 item was 4.06, indicating that the respondents agreed, knowing well that their business brands will develop in the future. Almost similarly, the Bl-4 item reached an average score of 4.08 , meaning that the respondents also agreed, always striving to achieve the future goal of this business. On the other side, the average score of the BI-5 item gained 3.40, signifying that the respondents tended to be neutral that their brands represent their organizational values, while the average score of the BI-6 item was 3.59, meaning that the respondents tended to agree that their business product/service marketing is guided by brand values. Regarding the $\mathrm{BI}-7$ item, the average score reached 3.65 , indicating that the respondents agreed, always trying to unify their business marketing activities. On the other side, the average score of the Bl-8 item was 3.45 , giving a clue that the respondents were neutral that the office layout, logo and clothing/uniform can represent the brand values. Overall, the average score of Brand Identity $(\mathrm{BI})$ variable obtained 3.62, categorized into "good" level.

Internal Brand (IB) was also measured by 8 statement items. The IB-1 got an average score of 3.88, meaning that the respondents agreed to always tell the employees for maintaining the values of the business. Meanwhile, the average IB-2 score was 3.45, suggesting that the respondents were neutral, regularly discussing the business brands. The 
average score of the IB-3 item reached 3.86, showing that the respondents agreed, always advising their employees to communicate the brand issues to the head/manager. As for the IB-4 item, the average score obtained was 4.11, indicating that the respondents also agreed, encouraging employees to promote consistent brand values through their behaviours in serving customers. Meantime, the IB-5 item reached an average score of 3.42 , suggesting that the respondents tended to be neutral that brand values can affect their staff development and employee placement decisions. The average score of the IB-6 item was 3.54 , meaning that the respondents agreed that through education and training, employees can become aware and support the brand promise. Next, the IB-7 item got an average score of 3.97, indicating that the respondents again agreed, always reviewing employee behaviours as part of the brand process and strengthening. Lastly, the average score of the IB-8 item was 4.09, signifying that the respondents tended to agree that employees should always deliver positive brand messages to customers. If summed up, the average score of Internal Brand (IB) variable was 3.79, belonging to "good" category.

Instrument Validity and Reliability. In the convergent validity testing, it was obtained a loading factor value of $>0.6$, an Average Variance Extracted (AVE) and Communality of $>$ 0.5. Based on the calculation, all items and indicators measuring Brand Orientation, Brand Identity, Internal Brand, Annual Turnover, Turnover Growth, and Net Income variables were declared valid. As for the instrument reliability testing, it was known a value of composite reliability $(\mathrm{CR})>0.7$ and Cronbach's Alpha value $>0.6$. Based on the calculation, all indicators measuring Brand Orientation, Brand Identity, Internal Brand, Annual Turnover, Turnover Growth, and Net Income variables were considered reliable.

The goodness of Fit Model aims: to know the ability of endogenous variables to explain the variance of exogenous variables, in PLS analysis using a determination coefficient ( $R$ square). The $R$-square value of each brand orientation and internal brand variables was similarly 0.895 while that of the brand identity was 0.895 . It was shown that the variances of brand orientation, internal brand, and brand identity variables explained by annual turnover, turnover growth, and net income variables were $89.5 \%$ and $89.6 \%$ while the remaining $10.5 \%$ and $10.4 \%$ were the contributions of other variables outside of this research model.

Hypothesis Testing. The hypothesis testing result of $H 1.1$ suggested that there was a positive and significant relationship between annual turnover and brand orientation. The testing result showed a path coefficient of 0.172 (positive value) and $T$-statistics value of $(1.995)>1.64$. As for the hypothesis testing result of $H 2.1$, it was indicated that there was a positive and significant relationship between annual turnover and brand identity. The testing result showed a path coefficient of 0.252 (positive value) and $T$-statistics value of $(2.770)>$ 1.64. Furthermore, the hypothesis testing result of $H 3.1$ also indicated that there was a positive and significant relationship between annual turnover and internal brand. The testing result showed a path coefficient of 0.185 (positive value) and $T$-statistics value of (1.938) > 1.64.

Moreover, based on the hypothesis testing result of H1.2, there was a positive and significant relationship between turnover growth and brand orientation. It was indicated by the path coefficient of 0.843 (positive value) and $T$-statistics value of $(74.292)>1.64$. The hypothesis testing result of $\mathrm{H} 2.2$ also indicated a positive and significant relationship between turnover growth and brand identity, in which the result showed a path coefficient of 0.793 (positive value) and $T$-statistics value of $(64.613)>1.64$. Similarly, the testing of hypothesis H3.2 also resulted in a positive and significant relationship between turnover growth and internal brand. This was indicated by the achievement of the path coefficient of 0.850 (positive value) and $T$-statistics value of $(69.972)>1.64$.

On another side, the hypothesis testing result of $\mathrm{H} 1.3$ found that there was a positive yet insignificant relationship between net income and brand orientation. The testing result showed a path coefficient of 0.056 (positive value) and $T$-statistics value of $(0.634)<1.64$. As for the testing of hypothesis $H 2.3$, there was also a positive yet insignificant relationship between net income and brand identity. It was indicated by the path coefficient of 0.060 (positive value) and $T$-statistics value of $(0.634)<1.64$. The last, the hypothesis testing result of $H 3.3$ similarly suggested that there was a positive yet insignificant relationship between 
net income and internal brand, in which the path coefficient reached 0.029 (positive value) and $T$-statistics value was $(0.300)<1.64$.

Table 2 - Description of SME Respondents

\begin{tabular}{|c|c|c|c|c|c|}
\hline Characteristic & Item & $\begin{array}{c}\text { Percentage } \\
(\%)\end{array}$ & Characteristic & Item & $\begin{array}{c}\text { Percentage } \\
(\%)\end{array}$ \\
\hline Gender & $\begin{array}{l}\text { Male } \\
\text { Female }\end{array}$ & $\begin{array}{l}59 \\
41\end{array}$ & \multirow{4}{*}{$\begin{array}{l}\text { 11. Partnership } \\
\text { Form } \\
\text { between SMEs } \\
\text { and the } \\
\text { Government }\end{array}$} & \multirow{2}{*}{$\begin{array}{l}\text { Linkage program/ } \\
\text { Product development } \\
\text { Revolving fund }\end{array}$} & 2 \\
\hline Age & $\begin{array}{l}20-40 \text { y.o } \\
>40-60 \text { y.o }\end{array}$ & $\begin{array}{l}55 \\
45\end{array}$ & & & $\begin{array}{l}3 \\
1\end{array}$ \\
\hline $\begin{array}{l}\text { The duration of serving } \\
\text { as Head/ Manager of } \\
\text { SME }\end{array}$ & $>2-5$ years & 60 & & $\begin{array}{l}\text { Product development } \\
\text { and human resource } \\
\text { training }\end{array}$ & 8 \\
\hline & $>5$ years & 40 & & $\begin{array}{l}\text { Product/ IT/ revolving } \\
\text { fund Development } \\
\text { Others }\end{array}$ & $\begin{array}{l}2 \\
8 \\
76\end{array}$ \\
\hline $\begin{array}{l}\text { The SME operating } \\
\text { duration }\end{array}$ & $\begin{array}{l}>2-5 \text { years } \\
>5 \text { years }\end{array}$ & $\begin{array}{l}58 \\
42\end{array}$ & \multirow{3}{*}{$\begin{array}{l}\text { 12. Partnership } \\
\text { Form } \\
\text { between SMEs } \\
\text { and Bankings }\end{array}$} & $\begin{array}{l}\text { No cooperation } \\
\text { Product development }\end{array}$ & $\frac{10}{4}$ \\
\hline Education & $\begin{array}{l}\text { SD/ equivalent } \\
\text { graduate } \\
\text { SMP/ equivalent } \\
\text { graduate } \\
\text { SMA/equivalent } \\
\text { graduate } \\
\text { D3 } \\
\text { S1 }\end{array}$ & $\begin{array}{l}1 \\
10 \\
65 \\
2 \\
22 \\
68\end{array}$ & & $\begin{array}{l}\text { Human resource } \\
\text { training } \\
\text { Revolving fund } \\
\text { Mismatch Fund } \\
\text { Product/ revolving fund } \\
\text { development } \\
\text { Others } \\
\text { No cooperation }\end{array}$ & $\begin{array}{l}1 \\
2 \\
1 \\
2 \\
7 \\
83\end{array}$ \\
\hline $\begin{array}{l}\text { Total of Employess } \\
\text { in Each SME Household }\end{array}$ & $\begin{array}{l}1-3 \text { people } \\
4-6 \text { people }\end{array}$ & $\begin{array}{l}68 \\
15\end{array}$ & & No cooperation & 83 \\
\hline $\begin{array}{l}\mathrm{N}=100 \mathrm{SME} \\
\text { Households } \\
\text { ( } 427 \text { people) }\end{array}$ & $\begin{array}{l}7-9 \text { people } \\
10-12 \text { people }\end{array}$ & $\begin{array}{l}13 \\
4\end{array}$ & \multirow{2}{*}{$\begin{array}{l}\text { 13. Preference of } \\
\text { SMEs on } \\
\text { Brand ideology }\end{array}$} & $\begin{array}{l}\text { Quite preferred } \\
\text { Preferred }\end{array}$ & 26 \\
\hline \multirow[t]{2}{*}{$\begin{array}{l}\text { Average SME Annual } \\
\text { Turnover } \\
\text { Average Net Income }\end{array}$} & \multicolumn{2}{|c|}{$\begin{array}{l}\text { IDR } 158,951,900 / \text { year } \\
\text { IDR } 106,595,000 / \text { year }\end{array}$} & & Very Preferred & 23 \\
\hline & & & $\begin{array}{l}\text { 14. Preparation of } \\
\text { SME }\end{array}$ & & \\
\hline $\begin{array}{l}\text { Classification of } \\
\text { SME Annual Turnover } \\
\text { (IDR) }\end{array}$ & $\begin{array}{l}5 \mathrm{M}-1,14 \mathrm{~B} \\
1,15 \mathrm{~B}-2,27 \mathrm{~B} \\
2,28 \mathrm{~B}-3,40 \mathrm{~B}\end{array}$ & $\begin{array}{l}98(\mathrm{~L}) \\
1(\mathrm{M}) \\
1(\mathrm{H})\end{array}$ & $\begin{array}{l}\text { Financial } \\
\text { Statement }\end{array}$ & $\begin{array}{l}\text { Sometimes preparing } \\
\text { Always preparing }\end{array}$ & $\begin{array}{l}31 \\
62\end{array}$ \\
\hline $\begin{array}{l}\text { Classification of } \\
\text { SME Net Income } \\
\text { (IDR) }\end{array}$ & $\begin{array}{l}1,5 \mathrm{M}-77 \mathrm{M} \\
78 \mathrm{M}-1,53 \mathrm{~B} \\
1,54 \mathrm{~B}-2,30 \mathrm{~B}\end{array}$ & $\begin{array}{l}98(\mathrm{~L}) \\
0(\mathrm{M}) \\
2(\mathrm{H})\end{array}$ & $\begin{array}{l}\text { 15. Submission of } \\
\text { SME } \\
\text { Financial } \\
\text { Statement }\end{array}$ & $\begin{array}{l}\text { Internal SME } \\
\text { External SME } \\
\text { Others }\end{array}$ & $\begin{array}{l}99 \\
0 \\
1\end{array}$ \\
\hline $\begin{array}{l}\text { Turnover Growth } \\
\text { during the last } 5 \text { years }\end{array}$ & $\begin{array}{l}\text { Decreasing } \\
\text { Fluctuating } \\
\text { Fixed } \\
\text { Increasing }\end{array}$ & $\begin{array}{l}17 \\
25 \\
18 \\
40\end{array}$ & $\begin{array}{l}\text { 16. SME Annual } \\
\text { Tax Statement }\end{array}$ & $\begin{array}{l}\text { Yes } \\
\text { No }\end{array}$ & $\begin{array}{l}64 \\
36\end{array}$ \\
\hline
\end{tabular}

Source: Primary Data.

Conversion of Path Diagram into Structural Model. Conversion of path diagrams in a measurement model aims to determine the effect of exogenous variables on endogenous variables as follows:

$$
\text { Equation 1: } \mathrm{BO}=0.172 \mathrm{AT}+0.843 \mathrm{TG}+0.056 \mathrm{NI}
$$

Where: BO: Brand Orientation; AT: Annual Turnover; TG: Turnover Growth; NI: Net Income.

In Equation 1, it was informed that: (1) the direct coefficient of $A T$ on BO was 0.172 , stating that AT positively and significantly affected BO. That was, the higher AT would tend to improve BO; (2) the direct coefficient of annual TG on BO was 0.843 , indicating that TG positively and significantly affected $\mathrm{BO}$. In other words, the higher TG would tend to improve $\mathrm{BO}$; (3) the direct coefficient of annual NI on BO was 0.056 , suggesting that $\mathrm{NI}$ positively yet 
insignificantly affected $\mathrm{BO}$. That was, the higher $\mathrm{NI}$ would also tend to improve $\mathrm{BO}$ although the improvement was not significant.

$$
\text { Equation 2: } \mathrm{BI}=0.252 \mathrm{AT}+0.793 \mathrm{TG}+0.060 \mathrm{NI}
$$

Where: BI: Brand Identity; AT: Annual Turnover; TG: Turnover Growth; NI: Net Income

In Equation 2, it was informed that: (1) the direct coefficient of $A T$ on $B I$ was 0.252 , suggesting that AT positively and significantly affected BI. It meant that the higher AT would tend to improve $\mathrm{BI} ;(2)$ the direct coefficient of annual TG on Bl was 0.793 , indicating that TG positively and significantly affected $\mathrm{BI}$. In other words, the higher the TG was, the more improved the BI would be; (3) the direct coefficient of annual NI on BI was 0.060 , signifying that $\mathrm{NI}$ positively yet insignificantly affected $\mathrm{BI}$. This indicated that the higher $\mathrm{NI}$ would tend to improve $\mathrm{BI}$ although the improvement was not significant.

Equation 3: IB $=0.185 \mathrm{AT}+0.850 \mathrm{TG}+0.029 \mathrm{NI}$

Where: IB: Internal Brand; AT: Annual Turnover; TG: Turnover Growth; NI: Net Income.

In Equation 3, it was informed that: (1) the direct coefficient of AT on IB was 0.185, stating that AT positively and significantly affected IB. That was, the higher AT would tend to improve IB; (2) the direct coefficient of annual TG on IB was 0.850 , indicating that TG positively and significantly affected IB. In other words, the higher the TG was, the more improved the IB would be; (3) the direct coefficient of annual NI on IB was 0.029 , suggesting that $\mathrm{NI}$ positively yet insignificantly affected IB. It meant that the higher $\mathrm{NI}$ would tend to improve IB although the improvement was not significant.

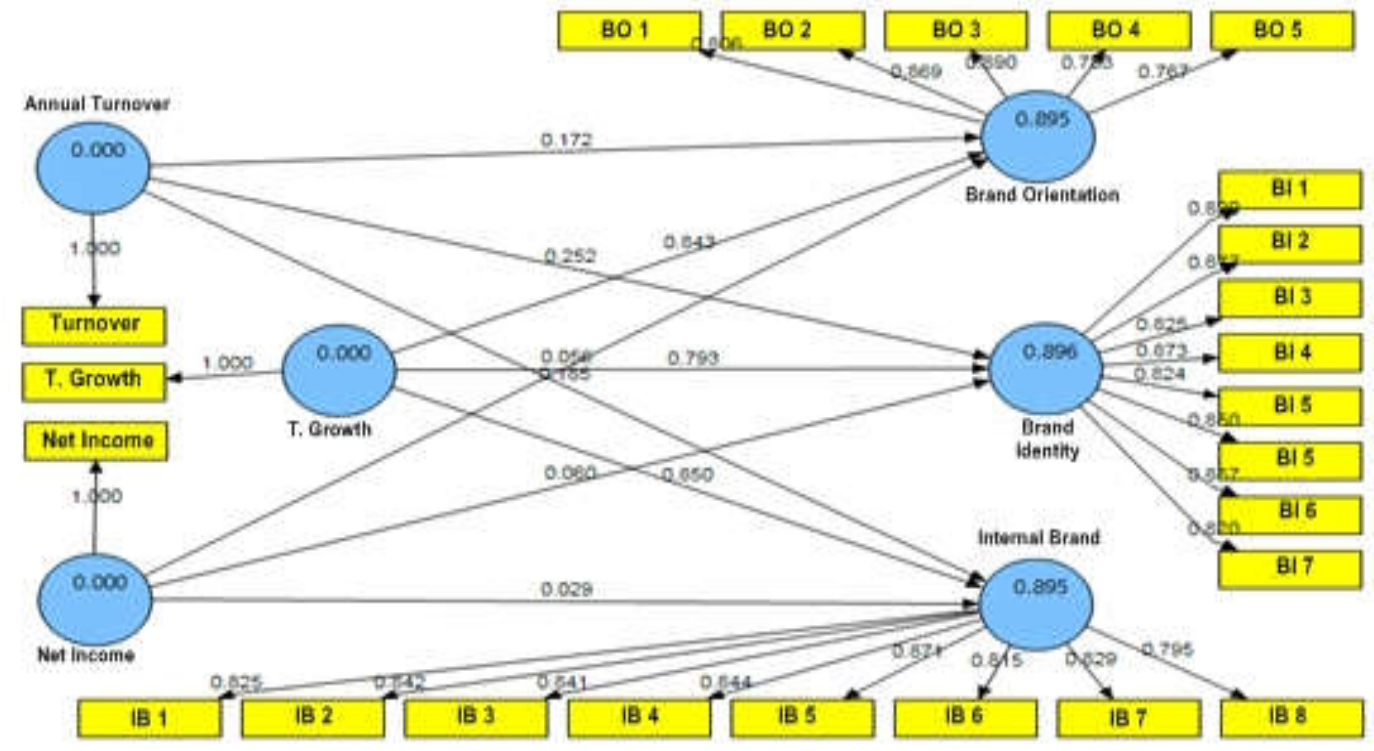

Figure 2 - Measurement Model Path Diagram

Dominant Effect. Exogenous variables that have a dominant effect on endogenous variables can be known through largest path coefficients. The analysis results showed that the turnover growth variable had the greatest path coefficient to the internal brand with a total effect of 0.850 , followed by the brand orientation's path coefficient of 0.843 and brand identity's path coefficient of 0.793 .

Effect Difference Testing of Annual Turnover Categories on Brand Orientation, Brand Identity, and Internal Brand. The effect difference testing of annual turnover categories on $\mathrm{BO}, \mathrm{BI}$ and IB were done using One Way ANOVA with the following hypotheses: 
- $\mathrm{H}_{0}$ : There is no significant effect difference between annual turnover categories on $\mathrm{BO}, \mathrm{BI}$ and IB;

- $\mathrm{H}_{1}$ : There is at least a pair of annual turnover categories significantly different on $\mathrm{BO}$, $\mathrm{BI}$, and IB.

The testing criterion states that if the probability is $\leq$ level of significance (alpha $=5 \%$ ), $\mathrm{H}_{0}$ will be rejected. Therefore, this research stated that there was at least one pair of annual turnover categories resulting in significantly different $\mathrm{BO}, \mathrm{BI}$, and IB. The effect difference testing of annual turnover categories on $\mathrm{BO}, \mathrm{BI}$, and IB informed that the statistical value of F-test for BO was 16.715 (prob. 0.000); that for BI was 5.795 (prob. 0.004), and that for IB was 5.037 (prob. 0.008) < alpha $(5 \%)$, causing $\mathrm{H}_{0}$ rejected. It can be stated that at least one pair of annual turnover categories on $\mathrm{BO}, \mathrm{BI}$ and IB was significantly different.

The significant effect difference in the annual turnover categories of $\mathrm{BO}, \mathrm{BI}$ and IB was found through LSD Test with the criterion if one pair of annual turnover categories obtains a probability of $\leq$ alpha $=5 \%$, it can be said that there is effect difference in the annual turnover categories of $\mathrm{BO}, \mathrm{BI}$ and $\mathrm{IB}$. The analysis results of the category effect difference informed that the high annual turnover resulted in the highest $\mathrm{BO}, \mathrm{BI}$ and $\mathrm{IB}$, which were significantly different from the low and moderate annual turnovers. Meanwhile, the low annual turnover resulted in the lowest $\mathrm{BO}, \mathrm{BI}$ and $\mathrm{IB}$, which were not significantly different from the moderate annual turnover, but significantly differed with the high annual turnover.

Effect Difference Testing of Turnover Growth Categories on Brand Orientation, Brand Identity, and Internal Brand. The effect difference testing of turnover growth categories on $\mathrm{BO}, \mathrm{BI}$ and IB were done using One Way ANOVA with the following hypotheses:

- $\mathrm{H}_{0}$ : There is no significant effect difference of turnover growth categories on $\mathrm{BO}, \mathrm{BI}$ and IB;

- $\mathrm{H}_{1}$ : There is at least a pair of turnover growth categories significantly different on $\mathrm{BO}$, $\mathrm{BI}$, and IB.

The testing criterion states that if the probability is $\leq$ level of significance (alpha $=5 \%$ ), $\mathrm{H}_{0}$ will be rejected. Therefore, in this research, it was said that there was at least one pair of turnover growth categories resulting in significantly different $\mathrm{BO}, \mathrm{BI}$, and IB. The results of the effect difference testing of turnover growth categories on $\mathrm{BO}, \mathrm{BI}$, and IB informed that the statistical value of $F$-test for BO was 6.667 (prob. 0.000); that for $\mathrm{BI}$ was 3.425 (prob. 0.020), and that for IB was 3.637 (prob. 0.016) < alpha (5\%), so $\mathrm{H}_{0}$ was rejected. In other words, it can be said that at least one pair of turnover growth categories on $\mathrm{BO}, \mathrm{BI}$ and IB was significantly different.

The significant effect difference in the turnover growth categories of $\mathrm{BO}, \mathrm{BI}$ and IB was found through LSD Test with the criterion if one pair of turnover growth categories obtains a probability of $\leq$ alpha $=5 \%$, it can be said that there is effect difference in the turnover growth categories of $\mathrm{BO}, \mathrm{BI}$ and $\mathrm{IB}$. The analysis results of the category effect difference informed that the increased turnover growth resulted in the highest $\mathrm{BO}, \mathrm{BI}$ and $\mathrm{IB}$, and it was not significantly different from the fixed turnover growth (BO), fluctuating and fixed turnover growth (BI), and fixed turnover growth (IB). However, it significantly differed with the decreasing and fluctuating turnover growth (BO), decreasing turnover growth (BI), and decreasing and fluctuating turnover growth (IB). Meanwhile, the decreasing turnover growth resulted in the lowest $\mathrm{BO}, \mathrm{BI}$ and $\mathrm{IB}$, which was not significantly different from the moderate annual turnover, but significantly differed with the increasing turnover growth.

Effect Difference Testing of Net Income Categories on Brand Orientation, Brand Identity, and Internal Brand. The effect difference testing of net income categories on $\mathrm{BO}, \mathrm{BI}$ and IB were carried out using One Way ANOVA with the following hypotheses:

- $\mathrm{H}_{0}$ : There is no significant effect difference between net income categories on BO, BI and IB;

- $\mathrm{H}_{1}$ : There is at least a pair of net income categories significantly different on BO, BI, and IB. 
The testing criterion mentions that if the probability is $\leq$ level of significance (alpha $=5 \%), \mathrm{H}_{0}$ will be rejected. Therefore, this research stated that there was at least one pair of net income categories resulting in significantly different $\mathrm{BO}, \mathrm{BI}$, and IB.

The results of the effect difference testing of net income categories on $\mathrm{BO}, \mathrm{BI}$, and $\mathrm{IB}$ informed that the statistical value of $F$-test for $\mathrm{BO}$ was 10.607 (prob. 0.000 ); that for $\mathrm{BI}$ was 5.214 (prob. 0.007), and that for IB was 3.235 (prob. 0.044 ) < alpha (5\%), so $\mathrm{H}_{0}$ was rejected. That was, at least one pair of turnover growth categories on $\mathrm{BO}, \mathrm{BI}$ and IB were significantly different.

The significant effect difference in the net growth categories of $\mathrm{BO}, \mathrm{BI}$ and $\mathrm{IB}$ was determined through LSD Test with the criterion if one pair of net income categories obtains a probability of $\leq$ alpha $=5 \%$, it can be said that there is effect difference in the net income categories of $\mathrm{BO}, \mathrm{BI}$ and $\mathrm{IB}$. The analysis results of the category effect difference informed that the high net income resulted in the highest $\mathrm{BO}, \mathrm{BI}$ and $\mathrm{IB}$, which was significantly different from the low and moderate net incomes. Meanwhile, the low net income resulted in the lowest $\mathrm{BO}, \mathrm{BI}$ and IB, which was not significantly different from the moderate net income but significantly differed with the high net income.

\section{DISCUSSION OF RESULTS}

Annual Turnover and Average Annual Turnover Difference of SMEs. In the ANOVA of this research, there were three composite steps used as dependent variables, namely $\mathrm{BO}, \mathrm{BI}$ and IB. SMEs were classified into three separate groups based on the annual turnover. The results of this research showed that, of 100 SME households in Kupang City, $98 \%$ of the SMEs had an annual turnover value of < IDR 1, 136, 666, 666, belonging to 'Low' category. The other $1 \%$ of the SMEs had an annual turnover value between IDR 1, 136, 666, 667 IDR 2, 268, 333, 332, belonging to 'Moderate' category. Meanwhile the rest $1 \%$ had an annual turnover value of > IDR 2, 268, 333, 333, belonging to 'High' category. From the results of the analysis, it can be concluded that SMEs have varying sizes and annual turnovers in the term of brands. SMEs with a higher annual turnover have a more positive attitude toward their brands and are more likely to develop BI and IB.

The LSD test showed more detailed information about the difference or variance in the average annual turnover of SMEs. The analysis results suggested that BO and IB had statistically significant differences in which the lowest annual turnover of the SMEs was < IDR 1, 136, 666, 666 and the highest annual turnover of the SMEs was > IDR 2, 268, 333, 333. Meanwhile, in the $\mathrm{BI}$, there was one pair that was statistically found to be significant, that was SMEs with the annual turnover < IDR 1, 136, 666, 666 and those with the annual turnover ranging between IDR 1, 136, 666, 667 - IDR 2, 268, 333, 332.

Based on the overall results, it can be concluded that all the hypotheses of $H 1.1$ (Better annual turnover is characterized by high brand orientation), $H 2.1$ (Greater annual turnover is characterized by greater investment in brand identity), and H3.1 (Greater annual turnover is characterized by greater investment in internal branding) are supported and accepted. It turns out that SMEs with a low annual turnover pay less attention to brands, while those with a higher annual turnover tend to give more priority to brands. The fact that $1 \%$ of SMEs had a high annual turnover value (more prioritizing brand ideology) is in line with the recognition of $45 \%$ respondents stating that they gave more priority to their brand ideology.

Turnover Growth and Average Turnover Growth Difference of SMEs. The turnover growth of SMEs during the last five years can be seen from the annual turnover experiencing a decrease, consistency (fixed), fluctuation and increase. The research results showed that, of 100 SME households operating in Kupang City, $40 \%$ of them experienced an increased annual turnover, $25 \%$ experienced a fluctuation, $18 \%$ had no changes in the annual turnover (fixed), while the rest $17 \%$ experienced a decrease in the annual turnover. SMEs reporting a declining, fixed or increasing annual turnovers were then compared one another using ANOVA. In this category, SMEs differed from one another in relation to $\mathrm{BO}$ and $\mathrm{BI}$. Meanwhile, in IB, there was no statistically significant difference or variance between the three groups. 
The average turnover growth difference of SMEs in Kupang City was measured using Least Square Difference test. The results of LSD test regarding brand ideology (BO, BI and $\mathrm{IB}$ ) informed that the increased turnover growth resulted in the highest $\mathrm{BO}, \mathrm{BI}$ and IB, and there was no statistically significant difference from the fixed turnover growth (BO), fluctuating and fixed turnover growth (BI), and fixed turnover growth (IB). However, it was significantly different from the decreasing and fluctuating turnover growth (BO), decreasing turnover growth $(\mathrm{BI})$ and decreasing and fluctuating turnover growth (IB). Meantime, the decreasing turnover growth resulted in the lowest $\mathrm{BO}, \mathrm{BI}$ and $\mathrm{IB}$, not significantly different from the fluctuating and fixed turnover growth but significantly different from the increasing turnover growth. Thus, It can be indicated that there is a difference between SME groups whose turnover growth decreases and increases $\left({ }^{* *} p<0,01\right)$, and between the SME groups whose turnover growth is fixed and increases $\left({ }^{*} p<0,05\right)$.

Based on the overall results, it can be concluded that all the hypotheses of $\mathrm{H} 1.2$ (Positive turnover growth is characterized by high brand orientation), $\mathrm{H} 2.2$ (Positive turnover growth is characterized by greater investment in brand identity), H3.2 (Positive turnover growth is characterized by greater investment in internal branding) are supported and accepted. It turns out those SMEs with a declining, fixed or fluctuating turnover growth less pay attention to the brands, while those with a high turnover growth more prioritize the brands.

Net Income and Average Net Income Difference of SMEs. The research results suggested that 100 SME households operating in Kupang City were classified into three separate groups based on the net income. Of the 100 SMEs, $98 \%$ had a net income of < IDR $767,666,665.7$ (Low), the other $2 \%$ had a net income of > IDR 1, 533, 833, 333 (High), and $0 \%$ had an annual turnover between IDR 1, 136, 666, 667 - IDR 2, 268, 333, 332 (Moderate).

The average net income difference of SMEs was measured using LSD test. The LSD test results on brand ideology $(\mathrm{BO}, \mathrm{BI}$, and $\mathrm{IB})$ suggested that the high net income resulted in the highest $\mathrm{BO}, \mathrm{BI}$ and $\mathrm{IB}$, which was significantly different from the low net income. Meanwhile, the low net income resulted in the lowest $\mathrm{BO}, \mathrm{BI}$ and IB, which was significantly different from the high net income.Thus, it can be indicated that there is a difference between SME groups whose net income increases and decreases $\left({ }^{* *} p<0,01\right)$.

Based on the overall results, it can be concluded that all the hypotheses of $H 1.3$ (Maximum net income is characterized by high brand orientation), H2.3 (Maximum net income is characterized by greater investment in brand identity), and H3.3 (Maximum net income is characterized by greater investment in internal branding) are not supported and rejected.

The rejection of the three hypotheses above was based on the results of hypothesis testing. The hypothesis testing result of $\mathrm{H} 1.3$ showed that the effect of net income to brand orientation resulted in a path coefficient of 0.056 with the $T$-statistics value of 0.634 , indicating that the path coefficient was positive and the $T$-statistics value was $<1.64$. It means that there is a positive yet insignificant relationship between net income and brand orientation. Meanwhile, the hypothesis testing result of $\mathrm{H} 2.3$ suggested that the effect of net income on brand identity resulted in a path coefficient of 0.060 with the $T$-statistics value of 0.634 , also indicating that the path coefficient was positive and the $T$-statistics value was < 1.64. That is, there is a positive yet insignificant relationship between net income and brand identity. Similarly, the hypothesis testing result of $\mathrm{H} 3.3$ showed that the effect of net income on internal brand yielded a path coefficient of 0.029 with the $T$-statistics value of 0.300 , indicating that the path coefficient was positive and the $T$-statistics value was $<1.64$. This means that there is a positive yet insignificant relationship between net income and internal brand.

Theoretical Implications. With regard to theoretical implications, it is assumed that in various situations, small companies generally always get benefits from brand guidelines developed by (in this context) large companies (Gabriellu and Balboni, 2010). This assumption needs to be questioned concerning whether small companies should or not forever take the chance of gaining benefits from the brand guidelines developed by large 
companies. However, there is a reason to assume that there are several differences identified in this study, which may derive from the fact that companies with a low annual turnover or a decreasing turnover growth are hesitant and reluctant to adopt a brand ideology. This is because they (small companies) consider that finding brands is only suitable to be applied to large companies with a greater financial and human resources.

\section{CONCLUSION}

This research was aimed to examine and analyze the higher financial performance of Small and Medium Enterprises characterized by a greater adaptation to brand ideology (brand orientation, brand identity, and internal brand).

Descriptive analysis of this research showed that of 100 SME households in Kupang City during the last five years, the average annual turnover reached IDR 158, 951, 900, - and the average net income was IDR 106, 595, 000, -. Furthermore, 98\% of the SME households had a low-categorized annual turnover and net income.

In average, the brand orientation (BO), brand identity (BI), and internal brand (IB) variables of SMEs in Kupang City are in "good" criteria.

SME annual turnover and turnover growth have a positive and significant effect on brand ideology (brand orientation, brand identity, and internal brand), but SME net income has a positive yet insignificant effect on brand ideology.

The contribution of annual turnover, turnover growth, and net income variables on brand orientation, brand identity, and internal brand variables was $89.5 \%$ in average, while the remaining $10.5 \%$ was the contribution of other variables that were not discussed in this study.

The research results in relation to the annual turnover suggested that companies (SMEs) with a low annual turnover tended to have less brand orientation and pay less attention to the brand identity and internal brand development. This supports the theory stating that a successful company is a company that has an obvious brand orientation (Wong and Merrilees, 2005).

Turnover growth effect on $\mathrm{BO}, \mathrm{BI}$ and IB are not significantly different. The differences can be determined by analyzing the results of $F$-Test and Least Square Difference testing. Statistically, significant differences are identified in relation to brand orientation, brand identity, and internal brand. Based on the testing results, it can be concluded that SMEs with a higher turnover growth pay more attention to their brand ideology:

- Overall, the results of this research supports and are in line with several recent studies stating that there is a difference between SMEs in terms of adaptation and implementation of marketing and brand ideology (Reijonen and Laukkanen, 2010).

- This research also examined the theory of Wong and Merrilees (2005) stating that the smallest SMEs experience brand barriers, such as lack of human resource, finance and time. This condition hampers SMEs in Kupang City to engage in paying attention to their brands.

\section{SUGGESTIONS}

For Small and Medium Enterprises (SMEs), the results of this study are expected to be a reference to increase or improve better annual turnover, positive turnover growth and maximum net income.

Small companies should better understand the importance of brand ideology including brand orientation, brand identity, and internal brand so that the effective SME management can be easier.

Small companies should be able to eliminate the reluctance and hesitation in adopting a brand ideology. Furthermore, to make SMEs more beneficial, they need to be equipped with branding tools. 
For local governments, in this case, referring to the Office of Industry and Trade as well as the Office of Cooperatives and SMEs, this research is expected to be an input in conducting a training and coaching for SMEs about the importance of brand ideology.

The last, it is recommended that future research develop the guidance model of branding tools according to the characteristics of SMEs with business variation, annual turnover and turnover growth rates that are different from each other, and include other variables that are not discussed in this research model.

\section{REFERENCES}

1. Aaker, D.A. (1991). Managing Brand Equity: Capitalizing on the Value of a Brand Name. New York: The Free Press.

2. Aaker, D.A. (1996). Measuring Brand Equity Across Products and Markets. California Management Review, 38(2), 102-120.

3. Aaker, D.A., \& Joachimsthaler, E. (2002). Brand Leadership. London: Simon \& Schuster UK Ltd.

4. Aurand, T.W., Gorchels, L., \& Bishop, T.R. (2005). Human Resource Management's Role In Internal Branding: An Opportunity For Cross-Functional Brand Message Synergy. Journal of Product \& Brand Management, 14(3), 163-169.

5. Badan Pusat Statistik. (2014). Kota Kupang dalam Angka 2013.

6. Baumgarth, C. (2010). Living The Brand: Brand Orientation In The Business-To-Business Sector. European Journal of Marketing, 44(5), 653-671.

7. Berthon, P., Ewing, M.T., \& Napoli, J. (2008). Brand management in Small and Mediumsized Enterprises. Journal of Small Business Management, 46(1), 27-45.

8. De Chernatony, L. (1999). Brand Management Through Narrowing the Gap Between Brand Identity and Brand Reputation. Journal of Marketing Management, 15(1-3), 157179.

9. De Chernatony, L., \& Segal-Horn, S., (2003). The Criteria For Successful Service Brands. European Journal of Marketing, 37(7/8), 1095-1118.

10. Ewing, M.T., \& Napoli, J., (2005). Developing and Validating A Multidimensional Nonprofit Brand Orientation Scale. Journal of Business Research, 58(6), 841-853.

11. Gabrielli, V., \& Balboni, B. (2010). SME Practice Towards Integrated Marketing Communications. Marketing Intelligence \& Planning, 28(3), 275-290.

12. Ghodeswar, B.M. (2008). Building Brand Identity In Competitive Markets:A Conceptual Model. Journal of Product \& Brand Management, 17(1), 4-12.

13. Gilmore, A., Carson, D., \& Grant, K., (2001). SME Marketing in Practice. Marketing Intelligence \& Planning, 19(1), 6-11.

14. Hankinson, P. (2001). Brand Orientation in The Top 500 Fundraising Charities in The UK. Journal of Product \& Brand Management, 10(6), 346-360.

15. Henkel, S., Tomczak, T., Heitmann, M., \& Herrmann, A. (2007). Managing Brand Consistent Employee Behaviour: Relevance and Managerial Control of Behavioural Branding. Journal of Product \& Brand Management, 16(5), 310-320.

16. Kapferer, J. (1997). Strategic Brand Management: Creating and Sustaining Brand Equity Long Term (2nd Ed). London: Kogan Page.

17. Keller, K.L. (1993). Conceptualizing, Measuring, and Managing Customer-Based Brand Equity. Journal of Marketing, 57(1), 1-22.

18. Keller, K.L. (2003). Strategic Brand Management - Building, Measuring, and Managing Brand Equity. London: Pearson Education Inc.

19. King, C., \& Grace, D. (2006). Exploring Managers' Perspectives of The Impact of Brand Management Strategies on Employee Roles with in a Service Firm. Journal of Services Marketing, 20(6), 369-380.

20. Krake, F.B.G.J.M. (2005). Successful Brand Management in SMEs: a New Theory and Practical Hints. Journal of Product \& Brand Management, 14(4), 228-238. 
21. Pemerintah Kota Kupang. (2014). Laporan Tahunan Penerapan Standar Pelayanan Minimal Pemerintah Kota Kupang/Laporan Akuntabilitas Kinerja Instansi Pemerintah (LAKIP) Kota Kupang 2013.

22. Lassar, W., Mittal, B., \& Sharma, A. (1995). Measuring Customer-Based Brand Equity. Journal of Consumer Marketing, 12(4), 11-19.

23. Laukkanen, T., Tuominen, S., \& Reijonen, H. (2010). Market Orientation and Brand Orientation: Drivers of SME Performance? Proceedings of the 39th European Marketing Academy Conference, Copenhagen, Denmark.

24. McDonald, M.H.B., de Chernatony, L., \& Harris, F., (2001). Corporate Marketing and Service Brands - Moving Beyond the Fast - Moving Consumer Goods Model. European Journal of Marketing, 35(3/4), 335-352.

25. Papasolomou, I., \& Vrontis, D., (2006). Building Corporate Branding Through Internal Marketing: The Case of The UK Retail Brand Industry. Journal of Product \& Brand Management, 15(1), 37 - 47.

26. Reid, M., Luxton, S., \& Mavondo, F. (2005). The Relationship between Integrated Marketing Communication, Market Orientation, and Brand Orientation. Journal of Advertising, 34(4), 11- 23.

27. Reijonen, H., \& Laukkanen, T. (2010). Customer relationship oriented marketing practices in SMEs. Marketing Intelligence \& Planning, 28(2), 115-136.

28. Tuominen, S., Laukkanen, T., \& Reijonen, H. (2009). Market Orientation, Brand Orientation, and Brand Performance in SMEs: Related Constructs? Proceedings of the Australian \& New Zealand Marketing Academy Conference, Melbourne, Australia.

29. Urde, M. (1994). Brand Orientation: A Strategy for Survival. Journal of Consumer Marketing, 11(3), 18-32.

30. Urde, M. (1999). Brand Orientation: A Mindset for Building Brands into Strategic Resources. Journal of Marketing Management, 15(1-3), 117-133.

31. Urde, M. (2003). Core Value-Based Corporate Brand Building. European Journal of Marketing, 37(7/8), 1017-1040.

32. Wong, H.Y., \& Merrilees, B. (2005). A Brand Orientation Typology for SMEs: a Case Research Approach. Journal of Product and Brand Management, 14(3), 155-162.

33. Wong, H.Y., \& Merrilees, B. (2007). Multiple Roles for Branding in International Marketing. International Marketing Review, 24(4), 384-408.

34. Wong, H.Y., \& Merrilees, B. (2008). The performance Benefits of Being Brand Oriented. Journal of Product and Brand Management, 17(6), 372-383. 